\title{
KORELASI ANTARA POLA PEIMBINAAN AKHLAK DENGAN PERILAKU PESERTA DIDIK KELAS XI PONDOK PESANTREN DARUL AMAN GOIMBARA MAKASSAR
}

\author{
Muhammad Rusmin B. \\ Fakultas Tarbiyah dan Keguruan UIN Alauddin Makassar \\ Jl. Inspeksi Kanal/Belakang Komp. Anggrek Minasa Upa \\ Email: rusmin_bersahaja@yahoo.co.id
}

\begin{abstract}
The results of the moral development of the students of class XI of the Darul Aman Gombara Islamic Boarding School in Makassar are quite good. This is based on a questionnaire distributed and interviews with several teachers, not found any students who have committed acts that violate the norms of behavior I morals. Behavior of students of class XI Darul Aman Gombara Makassar Islamic Boarding School which obtained the highest score was 87 and the lowest score was 67. The average value obtained from 30 students was 78.3. So it can be concluded that the behavior of students of class XI Darul Islamic Boarding School safe in Gombara Makassar is included in both categories. The relationship between moral development and the behavior of students in class XI Darul Aman Gombara Islamic Boarding School Makassar, namely the level of relationship is classified as very strong. In the correlation coefficient table and the t test results obtained rtable is $0.99>0.361$, then HO is rejected and $\mathrm{H} 1$ is accepted. This can be concluded that there is a correlation or the relationship between moral development with the behavior of students of class XI Darul Aman Gombara Islamic Boarding School in Makassar, with a very strong correlation level.
\end{abstract}

Keywords: correlations, behaviors, students

\section{PENDAHULUAN}

\section{A. Latar Belakang}

Pendidikan merupakan hal penting dan tidak dapat ditinggalkan dalam setiap kehidupan manusia. Manusia mampu mengangkat harkat dan martabat dirinya menuju peradaban budaya dan pola berpikir yang lebih maju, dinamis, dan ilmiah melalui jalur pendidikan. Pendidikan dalam Islam sangat memperhatikan penataan individual dan sosial yang membawa penganutnya pada pemelukan dan pengaplikasian akhlak Islam secara komprehensif. Bidang studi akidah akhlak sebagai bagian dari pendidikan agama Islam merupakan sub sistem kurikulum pendidikan nasional yang bertujuan untuk menanamkan akidah dan akhlak peserta didik guna mengangkat derajat dalam mencapai kebahagian dunia dan akhirat.

Banyak hal yang melatarbelakangi perubahan atau kemerosotan mental dan akhlak peserta didik yang tidak sesuai dengan ajaran agama Islam. Ironisnya lagi, nilai-nilai 
akhlakul karimah sudah sering ditinggalkan seperti adab kepada Allah swt, orang tua, guru, teman, dan makhluk lainnya.

Undang-Undang No. 20 tahun 2003 tentang Sistem Pendidikan Nasional, menyebutkan:

Pendidikan nasional bertujuan untuk mengembangkan potensi peserta didik agar menjadi manusia yang beriman dan bertakwa pada Tuhan Yang Maha Esa, berakhlak mulia, sehat, berilmu, cakap, kreatif, mandiri, dan menjadi warga negara yang demokratis serta bertanggung jawab. ${ }^{1}$

Tidak bisa dipungkiri bahwa pendidikan memiliki hubungan erat dengan pembinaan akhlak. Perkembangan terakhir umat Islam di Indonesia, tergambar dengan jelas pada merosotnya akhlak sebagian umat Islam. Penyimpangan moral terutama di kalangan remaja, bukan lagi sesuatu yang asing terdengar seperti tawuran, perkelahian, narkoba, dan pergaulan bebas. Akhlak dalam kehidupan sehari-hari merupakan hal yang sangat penting dalam bertingkah laku, dengan akhlak yang baik seseorang tidak akan terpengaruh pada hal-hal negatif.

Pesantren merupakan lembaga pembinaan berbasis agama Islam yang sangat berperan dalam pengembangan akhlak dan mental peserta didik untuk menghasilkan manusia yang berbudi pekerti luhur dan mengetahui nilai-nilai yang berhubungan dengan manusia, alam, dan Allah swt. Pondok Pesantren Darul Aman Gombara Makassar merupakan suatu lembaga pendidikan yang dijadikan sebagai tempat belajar dan membentuk manusia agar menjadi pribadi yang lebih baik sesuai dengan ajaran agama Islam, melalui pembelajaran tauhid, ta'limul mutaallim, tafsir al-qur'an, dan hadis.

Kepribadian tersebut berupa sikap yang ditampilkan oleh para santri yang dibina oleh para ustadz dan ustadzah dengan memberi pengajaran kepada santri. Di tempat inilah, peserta didik (santri) menerima berbagai macam pelajaran, mulai dari hal terkecil yaitu kebersihan bagi dirinya sendiri, asrama mereka, tempat belajar, masjid, dan sampai kepada proses pembinaan akhlak yang setiap waktu diajarkan serta dijadikan renungan bagi mereka untuk diamalkan dalam kehidupan sehari-hari.

\section{B. Rumusan Masalah}

Permasalahan dalan penelitian ini adalah bagaimana pola pembinaan ahlak peserta didik Kelas XI Pondok Pesantren Darul Aman Gombara Makassar, bagaimana perilaku peserta didik Kelas XI Pondok Pesantren Darul Aman Gombara Makassar dan bagaimana korelasi atau hubungan antara pola pembinaan akhlak dengan perilaku peserta didik Kelas XI Pondok Pesantren Darul Aman Gombara Makassar.

${ }^{1}$ Undang-Undang RI Nomor 20 Tahun 2003 tentang Sistem Pendidikan Nasional (Jakarta: Citra Umbara, 2006), h. 76. 


\section{KAJIAN TEORETIS}

\section{A. Pola Pembinaan Akhlak}

Pola adalah sistem, cara kerja atau bentuk (struktur) yang tetap, ${ }^{2}$ sedangkan pembinaan adalah usaha, tindakan dan kegiatan yang dilakukan secara efesien dan efektif untuk memperoleh hasil yang lebih baik. ${ }^{3}$ Jadi pola pembinaan adalah suatu sistem cara kerja ataupun struktur yang tetap tentang usaha, tindakan, dan kegiatan yang dilakukan secara efesien dan efektif untuk memperoleh hasil yang lebih baik.

Menurut Arifin, pembinaan yaitu usaha manusia untuk membimbing dan mengarahkan kepribadian serta kemampuan anak baik dalam pendidikan formal maupun non formal. ${ }^{4}$ Pembinaan memberikan arah penting pada masa perkembangan anak, khususnya dalam perkembangan sikap dan perilaku. Untuk itu, pembinaan bagi anakanak diperlukan saat dini guna memberikan arah dan penentuan pandangan hidupnya. Pembentukan akhlak dipengaruhi oleh faktor internal, yaitu pembawaan si anak dan faktor eksternal yaitu pendidikan dan pembinaan yang dibuat secara khusus. Pola pembinaan pada dasarnya diciptakan untuk menjalin hubungan sehari-hari dengan anakanak asuh.

Pola pembinaan disertai tindakan dari lembaga atau pengasuh untuk membentuk karakter anak. Pola pembinaan merupakan cara atau teknik yang dipakai oleh lembaga atau pengasuh dalam mendidik dan membimbing anak-anak asuhnya agar kelak menjadi orang yang berguna. Menurut Ibnu Maskawaih di dalam bukunya Sudarsono berpendapat bahwa pembinaan akhlak dititikberatkan kepada pembentukan mental anak atau remaja agar tidak mengalami penyimpangan. ${ }^{5}$

Pembinaan juga merupakan salah satu cara membantu orang tua menjalankan peranan yang penting bagi perkembangan anak selanjutnya. Dengan memberikan bimbingan dan pengalaman serta memberikan pengawasan, anak dapat menghadapi kehidupan yang akan datang dengan sukses, sebab di dalam keluarga yang merupakan kelompok sosial dalam kehidupan individu, anak akan belajar dan menyatakan dirinya sebagai manusia sosial dalam hubungan dan interaksi dengan kelompok.

Pola pembinaan adalah cara dalam mendidik, membimbing, memberikan pengalaman dan pengawasan terhadap anak didik agar kelak menjadi orang yang berguna, serta memenuhi kebutuhan fisik dan psikis yang akan menjadi faktor penentu dalam menilai dan mendeskripsikan. Pembinaan dapat meningkatkan mutu pribadi, pengetahuan, sikap, dan kemampuan serta kecakapan seseorang.

Demikian demikian, pembinaan dapat diartikan sebagai latihan untuk mengenal kemampuan dan mengembangkannya. Unsur yang utama dalam pembinaan ini adalah

\footnotetext{
${ }^{2}$ Pusat Bahasa Departemen Pendidikan Nasional, Depdikbud, Kamus Besar Bahasa Indonesia (edisi III; Jakarta: Balai Pustaka, 2005), h. 152.

${ }^{3}$ Pusat Bahasa Departemen Pendidikan Nasional, Depdikbud, Kamus Besar Bahasa Indonesia, h. 134.

${ }^{4}$ M. Arifin, Hubungan Timbal Balik Pendidikan Agama (Jakarta: Bulan Bintang, 2008), h. 30.

${ }^{5}$ Sudarsono, Etika Islam Tentang Kenakalan Remaja (Jakarta: Bina Aksara, 1989), h. 148.
} 
uswah hasanah (tauladan yang baik) dari para pembina, baik dari para ustadz dan para pengurus organisasi santri. Mereka harus memberikan contoh yang baik kepada seluruh santri karena seluruh kehidupan yang dilihat oleh para santri didengar dan dilakukan oleh mereka adalah pendidkan. Apabila yang dilihat dan didengar oleh santri adalah hal-hal yang baik, maka akan tertanam dalam dirinya pendidikan yang baik pula. Akan tetapi sebaliknya, jika yang dilihat adalah kehidupan yang negatif maka akan tertanam hal yang negatif pula dalam dirinya. Terdapat beberapa jenis pola pembinaan menurut Enung Fatimah diantaranya pembinaan oteriter, pembinaan permisif, dan pembinaan demokratis. Biasanya, pembinaan atau pendekatan yang dilakukan orang tua dalam berhubungan dan mendidik anak-anaknya adalah pembinaan otoriter. Pola pembinaan otoriter ditandai dengan ciri-ciri sikap orang tua yang kaku dan keras terhadap anak dalam menerapkan peraturan-peraturan. Orang tua bersikap memaksa dengan selalu menuntut kepatuhan anak agar bertingkah laku seperti yang dikehendakinya.

Orang tua tidak mempunyai pegangan mengenai bagaimana mereka harus mendidik, maka timbullah berbagai sikap orang tua yang mendidik menurut apa yang dianggap terbaik oleh mereka sendiri, diantaranya adalah dengan hukuman dan sikap acuh tak acuh. Sikap ini dapat menimbulkan ketegangan dan ketidaknyamanan, sehingga memungkinkan kericuhan di dalam rumah. ${ }^{6}$

Pembinaan permisif adalah seorang anak diberi kebebasan yang penuh dan diizinkan membuat keputusan sendiri tanpa mempertimbangkan orang tua serta bebas menentukan apa yang diinginkan. Pola asuh permisif dikatakan pola asuh tanpa disiplin sama sekali. Menurut Kartono dalam pola asuh permisif, orang tua memberikan pengarahan dan penjelasan kepada anak tentang apa yang sebaiknya dilakukan anak.

Berbeda dengan pembinanaan demokratis, dimana orang tua atau pendidik bersikap terbuka terhadap tuntutan dan pendapat yang dikemukakan anak, kemudian mendiskusikan hal tersebut bersama-sama. Pola ini lebih memuaskan perhatian pada aspek pendidikan dari pada aspek hukuman, orang tua atau pendidik memberikan peraturan yang luas serta memberikan penjelasan tentang sebab diberikannya hukuman serta imbalan tersebut. ${ }^{7}$ Pola asuh demokratis ditandai dengan sikap menerima, responsif, berorientasi pada kebutuhan anak yang disertai dengan tuntunan, kontrol, dan pembatasan. Sehingga penerapan pola asuh demokratis dapat memberikan keleluasaan kepada anak untuk menyampaikan segala persoalan yang dialaminya tanpa ada perasaan takut. Keleluasaan yang diberikan orang tua tidak bersifat mutlak akan tetapi ada kontrol dan pembatasan berdasarkan norma-norma yang ada. ${ }^{8}$ Dengan demikian, terjalin komunikasi yang baik antara orang tua dan anak.

${ }^{6}$ Enung Fatimah, Psikologi Perkembangan: Perkembangan Peserta Didik (Bandung: Pustaka Setia, 2008), h. 85 .

${ }^{7}$ Hurlock, Psikologi Perkembangan: Pengantar Dalam Berbagai Bagiannya (Yogyakarta: UGM Press, 2006), h. 99.

${ }^{8}$ Hurlock, Psikologi Perkembangan: Pengantar Dalam Berbagai Bagiannya, h. 102. 
Sedangkan akhlak akhlak berasal dari bahasa arab, jama' dari khuluqun' yang menurut bahasa diartikan budi pekerti, perangai, tingkah laku, atau tabi' at. ${ }^{9}$ Kata "akhlak" atau khuluk" keduanya terdapat dalam Al-Qur'an surah Al-Qalam/68: 4 sebagai berikut. ${ }^{10}$

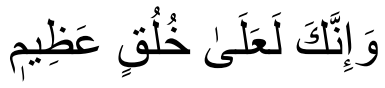

Terjemahnya:

Dan sesungguhnya kamu benar-benar berbudi pekerti yang agung. (Q.S Al-Qalam 68: 4)

Allah telah menjadikan engkau mempunyai rasa malu, mulia hati, pemberani, pemberi maaf, dan segala akhlak yang mulia. ${ }^{11}$ Tafsir ayat tersebut sangat jelas bahwa Allah SWT telah memberikan sifat-sifat akhlak pada diri manusia. Akhlak merupakan perhatian pertama dalam Islam, hal ini dapat dilihat dari misi kerasulan Nabi Muhammad saw yang utama yaitu untuk menyempurnakan akhlak yang mulia. Tafsir ayat tersebut jelas dapat dipahami bahwa Allah swt. telah memberikan sifat-sifat akhlak pada diri manusia.

Hanya saja manusia tidak menggunakan akhlak yang diberikan oleh Allah swt, malah manusia cenderung mengikuti langkah setan yang berakhlak tercela. Ayat tersebut di atas menunjukkan adanya isyarat bahwa akhlak yang mulia, tidak akan berada bersama kegilaan. Semakin baik akhlak manusia, maka akan semakin jauh ia dari kegilaan. ${ }^{12}$

Dalil di atas juga dapat dipahami bahwa akhlak adalah hal utama yang diajarkan dalam agama Islam. Dalam pergaulan di masyarakat, sangat banyak kita jumpai pertanyaan yang menunjukkan bahwa akhlak itu adalah perilaku yang baik. Hal ini tentu saja agak tidak sejalan dengan pandangan di atas, bahwa akhlak hanyalah gambaran makro (tanpa spesifikasi yang baik atau buruk) tentang perilaku manusia. Istilah akhlak ini berhubungan dengan sikap, budi pekerti, perangai dan tingkah laku. Demikian akhlak merupakan aspek ajaran Islam yang menyangkut norma-norma bagaimana manusia harus berperilaku, baik terhadap Allah Swt maupun terhadap sesama makhluk. ${ }^{13}$ Dengan demikian, akhlak sangat memegang peranan penting dalam kehidupan manusia agar tidak berada dalam kegilaan sehingga tidak mengikuti langkah setan yang memiliki akhlak tercela.

\footnotetext{
${ }^{9}$ A. Mustofa Al-Maraghi, Akhlak Tasawuf (Bandung: Pustaka Setia, 1997), h. 11.

10 Al-Qur'an dan Terjemah (Jakarta: PT. Tiga Serangkai Pustaka Mandiri, 2007), h. 564.

${ }^{11}$ A. Mustofa Al-Maraghi, Akhlak Tasawuf, h. 11.

${ }^{12}$ A. Mustofa Al-Maraghi, Akhlak Tasawuf, h. 49.

${ }^{13}$ Muniron dkk, Studi Islam di Perguruan Tinggi (Jember: STAIN Jember Press, 2010) , h. 46.
} 


\section{B. Perilaku Peserta Didik}

Perilaku adalah tindakan atau aktivitas dari manusia yang mempunyai arti yang sangat luas antara lain: berjalan, berbicara, menangis, tertawa, bekerja, kuliah, menulis, membaca, dan sebagainya. Dengan demikian dapat disimpulkan bahwa yang dimaksud perilaku adalah semua kegiatan atau aktivitas, baik yang diamati langsung maupun yang tidak dapat diamati oleh orang lain. Kartini Kartono mengatakan dalam buku yang dikutip oleh Herri Zan Pieter dan Namora Lumongga bahwa, perilaku merupakan proses mental dari reaksi seseorang yang sudah tampak dan belum tampak atau masih sebatas keinginan. ${ }^{14}$

Secara etimologi, kata perilaku merupakan kata benda abstrak yang menurut kamus besar bahasa Indonesia diartikan gerak, olah, laku, sikap atau perbuatan. Perilaku atau tingkah laku (behavior) merupakan daya gerak manusia yang didasarkan pada sistem syaraf yang terdiri atas komposisi sel-sel yang disebut neurons. Apabila mendapat stimulus, neurons itu akan merangsang gerakan elektronis guna merangsang gerakan neurons lainnya sehingga merangsang gerakan urat urat dan otot-otot tubuh.

Singgih D. Gunarsa membagi faktor-faktor yang mempengaruhi pembentukan kepribadian ke dalam dua kelompok yaitu faktor yang berasal dari anak sendiri dan faktor yang berasal dari lingkungan. ${ }^{15}$ Selain itu, faktor-faktor yang mempengaruhi perilaku peserta didik menurut Zakiyah Daradjat adalah faktor internal yang tidak dapat dipengaruhi oleh orang lain dan hanya bisa berubah atas kemauan diri sendiri. Kemudian faktor eksternal yang dipengaruhi oleh lingkungan maupun pergaulan. Faktor eksternal inilah yang bisa menjadi bahaya dan ancaman bagi kehidupan anak maupun bagi remaja yang baru tumbuh, salah satunya perkembangan teknologi. Kemajuan ilmu pengetahuan dan teknologi pada dasarnya baik dan berguna bagi kehidupan bangsa, akan tetapi kemajuan IPTEK itu telah ditumpangi dan disalahgunakan oleh sebagian manusia serakah yang tidak beragama dan kehidupannya ditentukan oleh hawa nafsu. Secara tidak sadar, para anak dan remaja terbawa oleh arus yang sering didengar dan disaksikan dalam acara kebudayaan yang ditayangkan oleh media elektronik.

Faktor lingkungan keluarga merupakan yang paling penting dalam mempengaruhi perilaku peserta didik. Apabila faktor negatif yang datang dari keluarga, misalnya orang tua tidak rukun, sering bertengkar di hadapan anak, maka akibatnya anak mengalami keterbelakangan kecerdasan, kegoncangan emosi akibat tekanan perasaan, dan kehilangan rasa kasih sayang dan sebagainya. ${ }^{16}$ Proses berperilaku, reaksi yang muncul itu diredam dengan usaha pemahaman terhadap ajaran agama Islam. Dengan demikian maka kesadaran pengalamannya dalam berperilaku akan terlaksana dengan baik juga. Manusia dilahirkan mewarisi sifat-sifat yang diturunkan oleh orang tuanya. Adapun yang

\footnotetext{
${ }^{14}$ Herri Zan Pieter dan Namora Lumongga, Pengantar Psikologi untuk Kebidanan (Jakarta: Kencana 2010), h. 27-28.

${ }^{15}$ Singgih D. Gunarsa, Psikologi untuk Membimbing (Cet. VII; Jakarta: PT. Gunung Mulia, 1995), h. 69.

${ }^{16}$ Zakiyah Daradjat, Remaja, Harapan dan Tantangan (Jakarta: Rahman, 1995), h. 46-60.
} 
diturunkan bukanlah sifat yang dimiliki yang telah tumbuh dengan matang karena pengaruh lingkungan, adat atau pendidikan, melainkan bawaan sifat-sifat sejak lahir. Sifat ini berupa sifat-sifat jasmani dan rohani.

Manusia sebagai makhluk sosial tidak akan terlepas dari lingkungan sekitarnya, yaitu lingkungan alam dan lingkungan pergaulan. Orang yang hidup di lingkungan alam yang subur tentu berbeda dengan orang yang hidup di lingkungan yang tidak subur. Orang yang hidup di lingkungan yang kurang subur lebih bisa menghadapi kesulitan dan tantangan hidup, begitupun dengan lingkungan pergaulan, setiap lingkungan dimana individu berada akan mempengaruhi karakter dan perilakunya.

Bentuk bentuk perilaku peserta didik secara umum dibedakan menjadi dua bentuk yaitu:

a. Bentuk perilaku positif

Namun demikian, dari beberapa penelitian diperoleh beberapa contoh sikap perilaku peserta didik yang positif, sebagaimana dikemukakan oleh Martiningsih Wibowo sebagai berikut:

1) Menunjukkan bahwa dia memiliki kompetensi-kompetensi (misalnya kompetensi kognitif, ditampilkan dalam kemampuan mengambil keputusan yang tepat, memiliki kompetensi sosial, ditampilkan dalam bentuk mampu menyelesaikan konflik sosial, memiliki kompetensi akademik, ditampilkan dalam bentuk pencapaian prestasi akademik yang cenderung/selalu tinggi, atau memiliki kompetensi vokasional, ditampilkan dalam bentuk membina kebiasaan kerja yang baik.

2) Menunjukkan bahwa dirinya berharga dan menunjukkan keyakinan bahwa dirinya mampu.

3) Menunjukkan kemampuan membina relasi dengan baik, misalnya mampu membina relasi dengan anggota keluarga, guru, orang dewasa, teman sebaya, dan lingkungan masyarakatnya.

4) Melakukan tindakan-tindakan yang menunjukkan bahwa ia memahami dan peduli pada orang lain serta peduli dengan lingkungan.

5) Menghargai aturan-aturan yang berlaku dan bertindak penuh tanggung jawab. ${ }^{17}$

b. Bentuk perilaku negatif

Menurut Mudjiran dkk, bentuk-bentuk perilaku negatif peserta didik yang sering dilakukan adalah:

1) Suka bolos/cabut sebelum pelajaran berakhir.

2) Tidak suka bergaul/suka menyendiri.

3) Suka berbohong kepada guru dan orang lain.

4) Suka berkelahi atau mengganggu temannya pada waktu belajar.

${ }^{17}$ Martiningsih Wibowo, Perilaku Remaja dan Pola Asuh Orang Tua (Jakarta: PT Raja Grasindo Persada, 1995), h. 2. 
5) Suka merusak fasilitas sekolah dan lain-lainnya.

6) Sering mencuri barang-barang dan kepunyaan orang lain.

7) Suka cari perhatian.

8) Ugal-ugalan, kebut-kebutan di jalanan, sehingga mengganggu lalu lintas, dan dapat membahayakan dirinya sendiri serta orang lain.

9) Kecanduan narkotika dan obat terlarang (narkoba).

10) Suka mabuk-mabukkan dan dapat mengganggu ketenangan orang lain. ${ }^{18}$

\section{Peserta Didik}

Peserta didik/santri adalah orang yang mendalami pengetahuan tentang agama Islam dengan pergi ke tempat yang jauh seperti pesantren. Santri juga bisa diartikan sebagai anak didik yakni orang yang mempunyai hak untuk mendapatkan pendidikan dari pendidik serta mempunyai kewajiban untuk mematuhi aturan-aturan yang berlaku selama dalam proses belajar-mengajar. ${ }^{19}$

Dari pengertian santri di atas maka penulis menyimpulkan bahwa santri adalah anak didik yang tinggal di suatu asrama yang bernama pondok pesantren untuk mengkaji ilmu Islam dengan tujuan menciptakan dan mengembangkan kepribadian muslim, yakni kepribadian yang beriman dan bertaqwa kepada Allah swt, berakhlak mulia, bermanfaat bagi masyarakat, dan menjadi contoh dalam masyarakat.

Tujuan umum pesantren adalah membina warga negara agar berkepribadian muslim sesuai dengan ajaran-ajaran agama Islam dan menanamkan rasa keagamaan pada semua segi kehidupan serta menjadi orang yang berguna bagi agama, masyarakat, dan negara. Adapun tujuan khususnya yaitu:

1. Mendidik santri untuk menjadi seorang muslim yang bertaqwa kepada Allah swt, berakhlak mulia, memiliki kecerdasan, keterampilan, dan sehat lahir batin sebagai warga negara yang berlandaskan pancasila.

2. Mendidik santri untuk menjadikan manusia muslim selaku kader-kader ulama dan muballigh yang berjiwa ikhlas, tabah, dan tangguh dalam mengamalkan ajaran Islam secara utuh dan dinamis.

3. Mendidik santri untuk memperoleh kepribadian dan memperoleh semangat kebangsaan agar dapat menumbuhkan manusia-manusia yang kelak bisa membangun bangsa dan negara.

4. Mendidik tenaga-tenaga penyuluh pembangunan mikro dan regional.

\footnotetext{
${ }^{18}$ Mudjiran dkk, Perkembangan Peserta Didik (Padang: Universitas Negeri Padang, 1999), h. 127.

${ }^{19}$ Nihayatus Sangadah, Hubungan Antara Kecerdasan Emosional dengan Reaksi Frustasi pada Pondok Pesantren Al-Huda Kebumen (Yogyakarta: Fakultas Dakwah, 2008), h. 3.
} 
5. Mendidik santri untuk membantu meningkatkan kesejahteraan sosial masyarakat lingkungan dalam rangka usaha pembangunan masyarakat. ${ }^{20}$

Dari uraian yang dikemukakan, maka dapat disimpulkan bahwa pondok pesantren memiliki peran penting dalam menanamkan ajaran Islam kepada setiap santri sehingga ilmu agama dan jiwa kemandiriannya dapat diaplikasikan dalam membangun bangsa dan negara.

\section{METODE PENELITIAN}

Jenis penelitian ini adalah penelitian hubungan (korelasi) artinya penelitian yang dilakukan untuk menggabungkan dua variabel atau lebih. ${ }^{21}$ yakni hubungan antara pembinaan akhlak dengan perilaku peserta didik Pondok Pesantren Darul Aman Gombara Makassar

Penelitian korelasional adalah suatu penelitian untuk mengetahui hubungan dan tingkat hubungan antara dua variabel atau lebih tanpa ada upaya untuk mempengaruhi variabel tersebut sehingga tidak terdapat manipulasi variabel. Adanya hubungan dan tingkat variabel ini penting karena dengan mengetahui tingkat hubungan yang ada, peneliti dapat mengembangkannya sesuai dengan tujuan penelitian. Jenis penelitian ini biasanya melibatkan ukuran statistik/tingkat hubungan yang disebut dengan korelasi.

Penelitian korelasional menggunakan instrumen untuk menentukan apakah, dan untuk tingkat apa, serta terdapat hubungan antara dua variabel atau lebih yang dapat dikuantitatifkan. Menurut Gay yang dikutip oleh Sukardi, penelitian korelasi merupakan salah satu bagian penelitian expostfacto karena biasanya peneliti tidak memanipulasi keadaan variabel yang ada dan langsung mencari keberadaan hubungan dan tingkat hubungan variabel yang direfleksikan dalam koefisien korelasi. ${ }^{22}$ Peneliti berusaha menggambarkan kondisi sekarang dalam konteks kuantitatif yang direfleksikan dalam variabel.

Penelitian korelasional dilakukan dalam berbagai bidang diantaranya pendidikan, sosial, maupun ekonomi. Penelitian ini hanya terbatas pada panafsiran hubungan antar variabel saja, tidak sampai pada hubungan kausalitas, tetapi penelitian ini dapat dijadikan acuan untuk dijadikan penelitian selanjutnya seperti penelitian eksperimen.

Penelitian ini berlokasi di Pondok Pesantren Darul Aman Gombara Makassar, jalan K.H. Abd. Jabbar Ashiry No. 1, Biring Kanaya Kota Makassar, Sulawesi Selatan 90242. Adapun yang menjadi objek dalam penelitian ini adalah seluruh peserta didik kelas XI

\footnotetext{
${ }^{20}$ Nihayatus Sangadah, Hubungan Antara Kecerdasan Emosional dengan Reaksi Frustasi pada Pondok Pesantren Al-Huda Kebumen, h. 6.

${ }^{21}$ Misbahuddin dan Iqbal Hasan, Analisis Data Penelitian dengan Statistik (Jakarta: Bumi Aksara, 2014), h. 8.

${ }^{22}$ Sukardi, Metodologi Penelitian Pendidikan, Kompetensi dan Praktiknya (Jakarta: Bumi Aksara 2004), h. 166.
} 
Pondok Pesantren Darul Aman Gombara. Pengumpulan data yang digunakan adalah dengan menggunakan angket dan dokumentasi.

Teknik pengumpulan data merupakan langkah yang paling strategis dalam penelitian, karena tujuan utama dari penelitian adalah mendapatkan data. Tanpa mengetahui teknik pengumpulan data, maka adapun prosedur pengumpulan data peneliti tidak akan mendapatkan data yang memenuhi standar data yang ditetapkan. Adapun tahapan yang ditempuh dalam penelitian ini adalah:

1. Tahap Persiapan

Tahap ini merupakan suatu tahap persiapan untuk melakukan suatu perlakuan, pada tahap ini langkah-langkah yang dilakukan peneliti adalah sebagai berikut:

a. Mengurus administrasi persuratan

b. Membuat draft proposal.

c. Melakukan survey di Pondok Pesantren Darul Aman Gombara Makassar yang akan menjadi lokasi penelitian.

2. Uji Hipotesis

Pengujian signifikan koefisien korelasi, uga dapat dihitung dengan uji t yang rumusnya ditunjukan pada rumus berikut: $\mathrm{t}_{\mathrm{h}}=\frac{r \sqrt{n-2}}{\sqrt{1-r^{2}}}$

Keterangan:

$\mathrm{t}$ hitung $=$ Nilai

$\mathrm{n} \quad=$ Jumlah sampel

$\mathrm{r} \quad=$ Nilai koefisien korelasi

\section{HASIL DAN PEMBAHASAN PENELITIAN}

\section{A. Deskriptif Pola Pembinaan Akhlak Peserta Didik Kelas XI Pondok Pesantren Darul Aman Gombara Makassar}

Berdasarkan hasil analisis data dengan menggunakan statistik deskriptif, dapat dikemukakan bahwa gambaran pembinaan akhlak peserta didik kelas XI Pondok Pesantren Darul Aman Gombara Makassar yang berhasil dikumpulkan dari responden sebanyak 30 peserta didik, diperoleh skor tertinggi adalah 87 dan skor terendah adalah 64. Nilai rata-rata yang diperoleh dari 30 peserta didik yaitu 76,7. Maka dapat disimpulkan bahwa pembinaan akhlak peserta didik kelas XI Pondok Pesantren Darul Aman Gombara Makassar termasuk kategori baik.

\section{B. Deskriptif Hasil Perilaku Peserta Didik Kelas XI Pondok Pesantren Darul Aman Gombara Makassar}

Berdasarkan hasil penelitian yang dianalisis dengan menggunakan statistik deskriptif, dapat dikemukakan bahwa perilaku peserta didik kelas XI Pondok Pesantren Darul Aman Gombara Makassar yang diperoleh skor tertinggi adalah 87 dan skor terendah adalah 67. Nilai rata-rata yang diperoleh dari 30 peserta didik yaitu 78,3. Maka 
dapat disimpulkan bahwa perilaku peserta didik kelas XI Pondok Pesantren Darul aman Gombara Makassar termasuk kategori baik.

\section{Korelasi antara Pembinaan Akhlak dengan Perilaku Peserta Didik kelas XI Pondok Pesantren Darul Aman Gombara Makassar}

Setelah melalui tahap analisis deskriptif dimana pada tahap itu digambarkan tentang bagaimana pembinaan akhlak peserta didik dan bagaimana hasil perilaku peserta didik kelas XI Pondok Pesantren Darul Aman Gombara Makassar. Berdasarkan hasil hitung, dapat diperoleh nilai 0.992, setelah itu, dikonfirmasikan pada tabel pedoman untuk memberikan interpretasi koefisien korelasi maka nilai 0.992 berada di interval 0.80 $>1.000$. Berdasarkan uji korelasi ini, maka dapat disimpulkan bahwa terdapat korelasi dengan tingkat hubungan yang sangat kuat antara pembinaan akhlak dengan hasil perilaku peserta didik kelas XI Pondok Pesantren Darul Aman Gombara Makassar.

Keberhasilan suatu proses pembinaan akhlak dipengaruh oleh banyak faktor. Faktor yang mempengaruhi perilaku (akhlak) anak adalah kebiasaan, keturunan, dan lingkungan. Lingkungan adalah segala apa yang melingkupi manusia dalam arti yang seluas-luasnya. Karena itu, lingkungan sangat mempengaruhi perilaku seorang peserta didik.

Berdasarkan uraian di atas dapat dikatakan bahwa dengan pembinaan akhlak yang baik merupakan salah satu faktor untuk meningkatkan perilaku peserta didik. Hal tersebut dapat dilihat dari besarnya kontribusi variabel $\mathrm{X}$ dan variabel $\mathrm{Y}$, yakni pada kelas tinggi variabel X (Pembinaan Akhlak) dengan variabel Y (Perilaku) peserta didik sebesar 43.33\% dan 26.66\%. Dengan demikian dapat disimpulkan bahwa pembinaan akhlak yang baik merupakan salah satu faktor yang dapat memberikan hubungan yang kuat terhadap perilaku peserta didik. Hal ini berarti semakin baik pembinaan akhlak peserta didik maka semakin tinggi pula hasil yang didapatkan dari perilaku peserta didik demikian pula sebaliknya.

\section{KESIMPULAN}

Berdasarkan data dari hasil penelitian yang telah dilakukan, maka dapat disimpulkan sebagai berikut:

1. Pembinaan akhlak peserta didik kelas XI Pondok Pesantren Darul Aman Gombara Makassar, tergolong baik hal ini berdasarkan pada angket yang disebar kepada peserta didik dan wawancara terhadap beberapa guru, tidak ditemukan adanya peserta didik yang pernah melakukan perbuatan yang melanggar normanorma perilaku/akhlak.

2. Perilaku peserta didik kelas XI Pondok Pesantren Darul Aman Gombara Makassar, setelah melakukan pengolahan data dilihat pada interval nilai tertinggi 85-87 dengan frekuensi 4 dari 30 responden berada pada termasuk baik.

3. Terdapat hubungan antara pembinaan akhlak dengan perilaku peserta didik kelas XI Pondok Pesantren Darul Aman Gombara Makassar. Dalam tabel koefisien 
korelasi dan hasil uji t diperoleh rhitung rtabel yakni 0,99>0,361. Maka $\mathrm{H}_{0}$ ditolak dan $\mathrm{H}_{1}$ diterima. Hal ini dapat ditarik kesimpulan bahwa terdapat hubungan antara pembinaan akhlak dengan perilaku peserta didik kelas XI Pondok Psantren Darul Aman Gombara Makassar, dengan tingkat hubungan yang sangat kuat.

\section{DAFTAR PUSTAKA}

Al-Maraghi, Ahmad Mustafa. Akhlak Tasawuf, Bandung: Pustaka Setia, 1997.

Al-Qur;an dan Terjemah, Jakarta: PT. Tiga Serangkai Pustaka Mandiri, 2007.

Daradjat, Zakiyah. Remaja, Harapan dan Tantangan, Jakarta: Rahman, 1995.

Fatimah, Enung. Psikologi Perkembangan; Perkembangan Peserta Didik, Bandung: Pustaka Setia, 2008.

Gunarsa, Singgih D., Psikologi untuk Membimbing, Cet. VII; Jakarta: PT. Gunung Mulia, 1995.

Hurlock. Psikologi Perkembangan: Pengantar Dalam Berbagai Bagiannya, Yogyakarta: UGM Press, 2006.

Misbahuddin dan Iqbal Hasan, Analisis Data Penelitian dengan Statistik, Jakarta: Bumi Aksara, 2014.

Mudjiran dkk. Perkembangan Peserta Didik, Padang: Universitas Negeri Padang, 1999.

Muniron dkk. Studi Islam di Perguruan Tinggi, Jember: STAIN Jember Press, 2010.

M Arifin, Hubungan Timbal Balik pendidikan Agama, Jakarta: Bulan Bintang, 2008.

Pusat Bahasa Departemen Pendidikan Nasional, Depdikbud. Kamus Besar Bahasa Indonesia, ed. III; Jakarta: Balai Pustaka, 2005.

Sudarsono. Etika Islam Tentang Kenakalan Remaja, Jakarta: Bina Aksara, 1989.

Sukardi. Metodologi Penelitian Pendidikan, Kompetensi dan Praktiknya, Jakarta: Bumi Aksara 2004.

Sangadah, Nihayatus. Hubungan Antara Kecerdasan Emosional dengan Reaksi Frustasi pada Pondok Pesantren Al-Huda Kebumen, Yogyakarta: Fakultas Dakwah, 2008.

Undang-Undang RI Nomor 20 Tahun 2003 tentang Sistem Pendidikan Nasional, Jakarta: Citra Umbara, 2006. 
Wibowo, Martiningsih. Perilaku Remaja dan Pola Asuh Orang Tua, Jakarta: PT Raja Grasindo Persada, 1995.

Zan Pieter, Herri dan Namora Lumongga. Pengantar Psikologi untuk Kebidanan, Jakarta: Kencana 2010. 